\title{
Agricultural Accidents: A Study of 132 Patients Seen at Addenbrooke's Hospital, Cambridge, in 12 Months
}

\author{
D. K. C. COOPER,* M.B., B.S.
}

Summary : In a 12-month study 132 patients injured in agricultural accidents were treated at the Accident Service of Addenbrooke's Hospital, Cambridge. Agricultural machinery and implements were concerned in $50 \%$ of the accidents and animals in $10 \%$. The state of immunity against tetanus of these patients was found to be extremely low, only $9 \%$ being fully immunized, and $56 \%$ having never received a course of prophylactic adsorbed tetanus toxoid.

While prevention is obviously the only real solution to accidents of any nature, legislation is not enough to achieve this, and the final responsibility lies with the farmworker to ensure that all safety precautions are followed.

\section{Introduction}

In the 12-month period from 1 July 1966 to 30 June 1967 17,242 new patients attended the Accident Service of Addenbrooke's Hospital, Cambridge. Of these, 132 had been involved in accidents occurring on farms or while following some form of agricultural occupation. Purely domestic accidents-that is, occurring within the farmhouse, etc.- have not been included in this study.

Accidents occurring in any agricultural region are obviously to some extent related to the type of farming carried out locally. Arable farming predominates around Cambridge, though patients who had sustained injuries on exclusively poultry or dairy farms were also seen.

\section{Analysis of Survey}

A total of 132 patients (125 male and 7 female) were injured during the 12 months' survey. Of these accidents nine occurred to children ( 5 male and 4 female)-that is, persons who had not left school or who were under the age of 15 years. All of these children lived on farms. Of the three adult women injured, two were farmers' wives and one was a farm worker. The occupations of the 120 adult men injured are given in Table I. The work of the scientific assistants, corn merchants, and treefellers involved had taken them to the farms on those occasions, and the one factory worker injured was helping on a farm at the time of his accident. Almost $95 \%$ of those injured were professional farmers or farm workers.

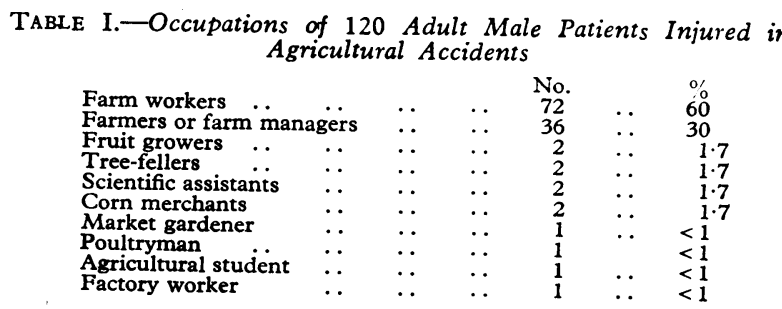

Age Distribution.-The age distribution of those injured is shown in Table II.

Seasonal Distribution.-The month of injury is given in Table III. There was a peak accident rate during the late

* Senior House Officer, Accident Service, Addenbrooke's Hospital, Cambridge. Present address: National. Heart Hospital, London W.1. summer and autumn, which coincided with the harvesting months.

TABLE II.-Age Distribution of 132 Patients Involved in Agricultural Accidents

\begin{tabular}{ll|r|r|r|r|r|r|r}
\hline Age & $\ldots$ & -10 & -20 & -30 & -40 & -50 & -60 & -70 \\
No. of patients & $\cdots$ & 1 & 15 & 23 & 23 & 28 & 22 & 20 \\
\hline
\end{tabular}

TABLE III.-Seasonal Distribution of 132 Patients Involved in Agricultural Accidents

\begin{tabular}{|c|c|c|c|c|c|c|c|c|c|c|c|c|c|}
\hline & & \multicolumn{6}{|c|}{1966} & \multicolumn{5}{|c|}{1967} & \\
\hline $\begin{array}{l}\text { Month } \\
\text { No. of patients }\end{array}$ & $\because$ & Ju. & A. & $\begin{array}{l}\mathrm{S} . \\
16\end{array}$ & O. & $\mathrm{N}_{8}$ & D. & $\mathrm{J}_{6}$ & $F_{\dot{9}}$ & $M_{9}$ & A. & $\begin{array}{l}\mathrm{M} . \\
12\end{array}$ & \\
\hline
\end{tabular}

Distance of Accident from Cambridge.-The Accident Service of Addenbrooke's Hospital serves a population of about 300,000. Ninety-seven per cent. of the accidents occurred within a $20-$ mile $(32-\mathrm{km}$.) radius of Cambridge, and $3 \%$ (4 accidents) occurred at about 45 to 50 miles $(72$ to $80 \mathrm{~km}$.) from Cambridge. These four included two patients with head injuries who were transferred from other hospitals for specialist neurosurgical care.

Eighty-seven patients attended the Accident Service direct, 41 saw their general practitioners first, and four were referred from other hospitals. One hundred and fifteen patients attended on the day of injury and the remaining 17 at least one day after the accident.

Admissions.-Thirteen of the 132 patients required admission. The causes of these accidents and the lengths of the patients' stay in hospital are given in Table IV. Apart from the one patient who died, the average length of stay was 10.6 days.

TABLe IV.-Analysis of 13 Patients Admitted to Addenbrooke's Hospital Following Agricultural Accidents

\begin{tabular}{|c|c|c|c|c|c|}
\hline $\begin{array}{l}\text { Case } \\
\text { No. }\end{array}$ & $\begin{array}{r}\mathbf{S} \\
\text { and }\end{array}$ & ex & $\begin{array}{l}\text { Cause } \\
\text { of Accident }\end{array}$ & $\begin{array}{l}\text { Injury } \\
\text { Sustained }\end{array}$ & $\begin{array}{l}\text { Length of } \\
\text { Stay in } \\
\text { Hospital } \\
\text { in Days }\end{array}$ \\
\hline 1 & $\mathbf{M}$ & 14 & Grain auger & Partial amputation left & \\
\hline 36 & & 65 & $\begin{array}{l}\text { Fall } 20 \mathrm{ft} . \\
\text { ladder }\end{array}$ & $\begin{array}{l}\text { Index tinger } \\
\text { Fracture left radius, } \\
\text { fracture pelvis, sprain }\end{array}$ & 2 \\
\hline 37 & $M$ & 8 & $\begin{array}{l}\text { Fall from trailer; } \\
\text { crushed between } \\
\text { wheel and trailer }\end{array}$ & $\begin{array}{l}\text { Crush injury to chest- } \\
\text { traumatic asphyxia }\end{array}$ & $\begin{array}{r}4 \\
11\end{array}$ \\
\hline 41 & $M$ & 47 & $\begin{array}{l}\text { Jumped from lorry- } \\
\text { landed awkwardly }\end{array}$ & $\begin{array}{l}\text { Fracture-dislocation } \\
\text { left ankle }\end{array}$ & 6 \\
\hline 42 & $M$ & 27 & Gored by pig & $\begin{array}{l}\text { Extensive contaminated } \\
\text { wounds right leg }\end{array}$ & 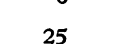 \\
\hline $\begin{array}{l}43 \\
54\end{array}$ & & $\begin{array}{l}20 \\
15\end{array}$ & $\begin{array}{l}\text { Tractor overturned } \\
\text { Lorry tailboard fell on } \\
\text { to left knee }\end{array}$ & $\begin{array}{l}\text { Multiple skull fractures } \\
\text { Extensive soft-tissue }\end{array}$ & 5 (died) \\
\hline 55 & & 69 & Fall from trailer & $\begin{array}{l}\text { Fracture neck of left } \\
\text { femur }\end{array}$ & 8 \\
\hline $\begin{array}{l}57 \\
58\end{array}$ & & $\begin{array}{l}45 \\
47\end{array}$ & $\begin{array}{l}\text { Fall from lorry } \\
\text { Turkey tendon-pulling } \\
\text { machine }\end{array}$ & $\begin{array}{l}\text { Fractured skull } \\
\text { Avulsion right thumb, } \\
\text { index finger, and } \\
\text { second metacarpal }\end{array}$ & $\begin{array}{r}10 \\
7\end{array}$ \\
\hline 59 & & 41 & $\begin{array}{l}\text { Metal foreign body } \\
\text { from knife }\end{array}$ & Perforation left cornea & $\begin{array}{r}32 \\
4\end{array}$ \\
\hline 128 & $\mathbf{M}$ & 57 & $\begin{array}{l}\text { Fall while carrying } \\
\text { heavy sack }\end{array}$ & Minor head injuries & 2 \\
\hline 132 & $\mathbf{M}$ & 59 & Fall from ladder & $\begin{array}{l}\text { Fractured skull. Rup- } \\
\text { tured left tympanic } \\
\text { membrarse }\end{array}$ & 11 \\
\hline
\end{tabular}

Deaths.-One patient, a farm worker aged 20, died from brain damage, and skull fractures resulting from crush injuries sustained when the tractor he was driving overturned. 
Permanent Disability.-Seventeen patients were left with some permanent disability as the result of their injuries, though in several cases this disability was only minor. Table $\mathrm{V}$ lists the causes of these accidents and the injuries sustained. Ten of the 17 were caused by machines, with augers playing a major part. In nine patients the hand or fingers were the sites of injury.

Table V.-Causes of Permanent Disability Resulting from Agricultural Accidents in 17 Patients

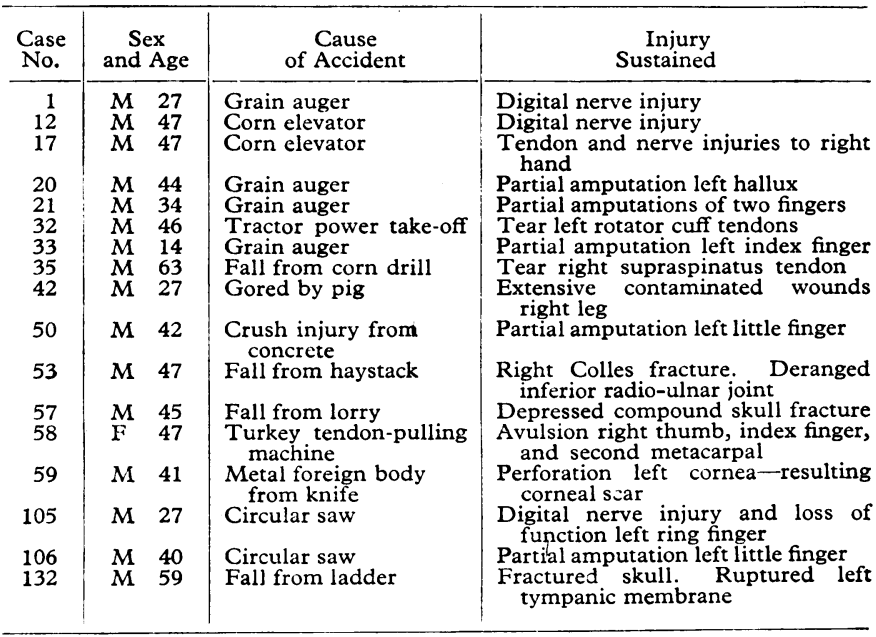

Duration of Hospital Outpatient Care.-After initial attention 66 patients required further outpatient attendances ranging from 1 day to 10 months, with an average of $6 \frac{1}{4}$ weeks. If the permanently disabled are excluded from these figures the period of outpatient attendance was from 1 day to 18 weeks, with an average of $3 \frac{1}{2}$ weeks. Thirty-nine patients were referred to their own doctors after initial management ; generally these were the most trivial cases which would not require further hospital facilities. Twenty-seven patients required no further attention after initial treatment. Most patients attending an accident service are followed up until such recovery as can be expected has occurred. Therefore the period of follow-up gives some guide to the length of time of at least partial incapacity of the patient to carry out his normal working duties. The 49 patients who were only temporarily disabled and who were followed up at the Accident Service were at least partially incapacitated for a total of about 1,200 work days. Of even greater economic significance is the fact that much of this disability occurred at a time when work on the farm was at its height, when incapacity could least be afforded.

Body Distribution of Injuries.-The extremities were involved in no fewer than 66 accidents $(50 \%)$, the hands being injured on 52 occasions (39\%) and the feet on 14 occasions (11\%). Twenty-six accidents involved the right hand and 26 the left hand. Other regions injured are listed in Table VI. Thirty-four injuries, including traumatic amputations, involved one or more fractured bones. Nineteen of these involved the small bones of the hand or foot, including the digits. There were three skull fractures. Fourteen fractures were compound. A fracture-dislocation of the ankle was seen, and there were three

TABLE VI.-Body Distribution of the 132 Injuries Resulting from

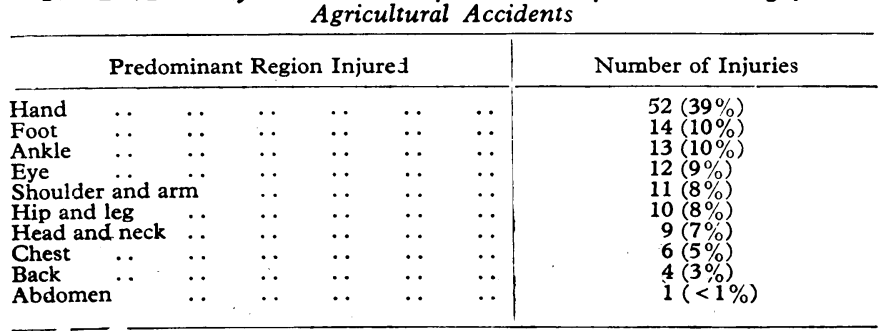

other dislocations. These involved shoulder, sternoclavicular, and proximal interphalangeal joints.

\section{Types of Injury}

There was a great diversity of injury, only the main types sustained being listed in Table VII. Obviously there was some overlap between the various categories, so the injuries have been listed under the category of the predominant lesion.

TABle VII.-Classification of Predominant Injuries Sustained in 132

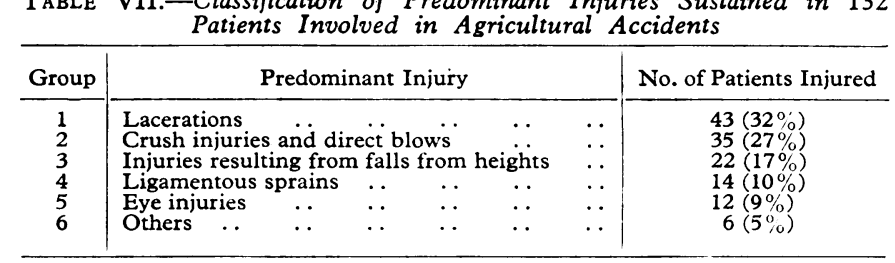

\section{Group 1. Lacerations}

Forty-three patients suffered injuries which were predominantly of this type. In all, 29 involved the hand or fingers and five involved the foot or toes. In four patients amputation or partial amputation of fingers (three) or toes (one) occurred at the time of the injury, and in two further cases partial amputation of the fingers was carried out at operation. Excluding the amputated digits, two patients suffered combined nerve, tendon, and bone injuries. There were two further injuries involving nerves, one further involving tendons, and three further fractures. Five of these patients underwent skin grafting.

The causes of injury were many and varied, but farm machinery and implements were implicated in a large proportion, as shown in Table VIII. Animals were involved in only two cases (Table IX), one being a serious goring from a pig

TABLE VIII.-Agricultural Machinery and Implements Involved in

\begin{tabular}{|c|c|c|c|c|c|c|c|c|}
\hline $\begin{array}{c}\text { Machine } \\
\text { or Implement }\end{array}$ & & Total & $\begin{array}{l}\text { Lacer- } \\
\text { ations }\end{array}$ & Crush & Falls & Sprains & Eye & Other \\
\hline 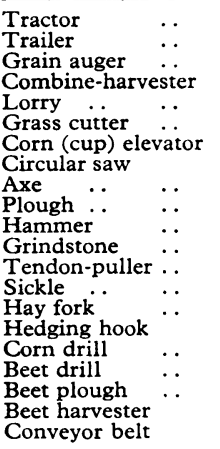 & 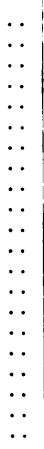 & $\begin{array}{r}12 \\
10 \\
6 \\
5 \\
5 \\
4 \\
3 \\
3 \\
3 \\
2 \\
2 \\
2 \\
1 \\
1 \\
1 \\
1 \\
1 \\
1 \\
1 \\
1 \\
1\end{array}$ & $\begin{array}{l}2 \\
2 \\
6 \\
2 \\
4 \\
3 \\
3 \\
3 \\
2\end{array}$ & $\begin{array}{l}8 \\
4 \\
1\end{array}$ & $\begin{array}{l}1 \\
1 \\
3\end{array}$ & $\begin{array}{l}1 \\
3 \\
1 \\
1\end{array}$ & 1 & 1 \\
\hline Total & .. & $66(50 \%)$ & 32 & 17 & 7 & 6 & 3 & 1 \\
\hline
\end{tabular}

TABLE IX.-Animals Involved in Agricultural Accidents to Patients

\begin{tabular}{|c|c|c|c|c|c|c|c|c|c|}
\hline \multicolumn{3}{|c|}{ Animal } & \multirow{2}{*}{$\begin{array}{c}\text { Total } \\
4 \\
3 \\
2 \\
1 \\
1 \\
1 \\
1\end{array}$} & \multirow{2}{*}{$\begin{array}{c}\begin{array}{c}\text { Lacer- } \\
\text { ations }\end{array} \\
1\end{array}$} & \multirow{2}{*}{ 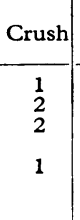 } & \multirow{2}{*}{$\frac{\text { Falls }}{2}$} & \multirow{2}{*}{$\frac{\text { Sprains }}{1}$} & \multirow{2}{*}{ Eye } & \multirow{2}{*}{$\begin{array}{c}\text { Other } \\
1\end{array}$} \\
\hline $\begin{array}{l}\text { Horse } \\
\text { Bullock } \\
\text { Cow } \\
\text { Pig } \\
\text { Pony } \\
\text { Foal } \\
\text { "og } \\
\text { Wild " ca }\end{array}$ & $\begin{array}{l}\ldots \\
\ldots \\
\ldots \\
\cdots \\
\ldots\end{array}$ & $\begin{array}{l}. . \\
\because \\
\because \\
\because \\
\cdots\end{array}$ & & & & & & & \\
\hline $\mathrm{Tc}$ & & $\ldots$ & $13(10 \%)$ & 2 & 6 & 2 & 2 & 0 & 1 \\
\hline
\end{tabular}

(Case 42 below). The second concerned a 15-year-old farm hand who claimed he had been clawed and bitten by a "wild" cat. 
Some accidents are worthy of particular mention.

Case 21.-A 34-year-old farmer put his hand into the grain covering an auger (Fig. 1) to pull out a small stick. His left ring and middle fingers were partially amputated (Fig. 2). This accident could not have happened had the guard, which by law should cover the exposed end of the machine, been in place. Several farmers admitted that they used their augers without guards, as they believed this led to increased efficiency of the machine.

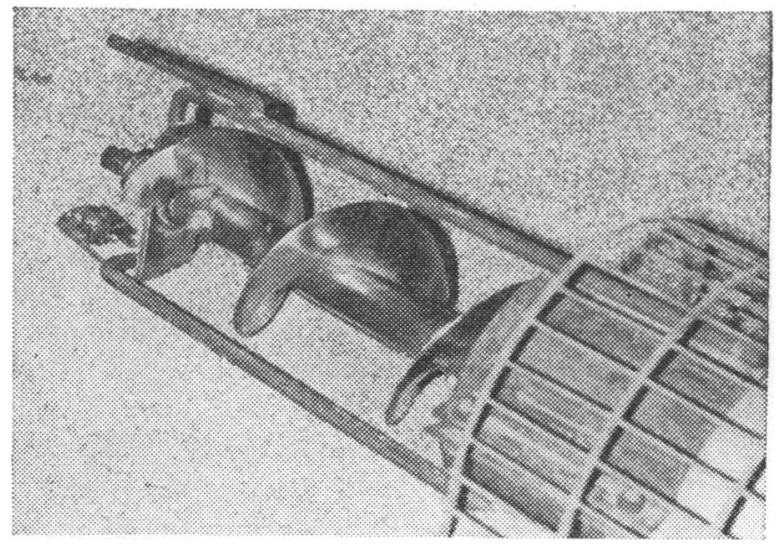

FIG. 1.-Grain auger with guard drawn back.

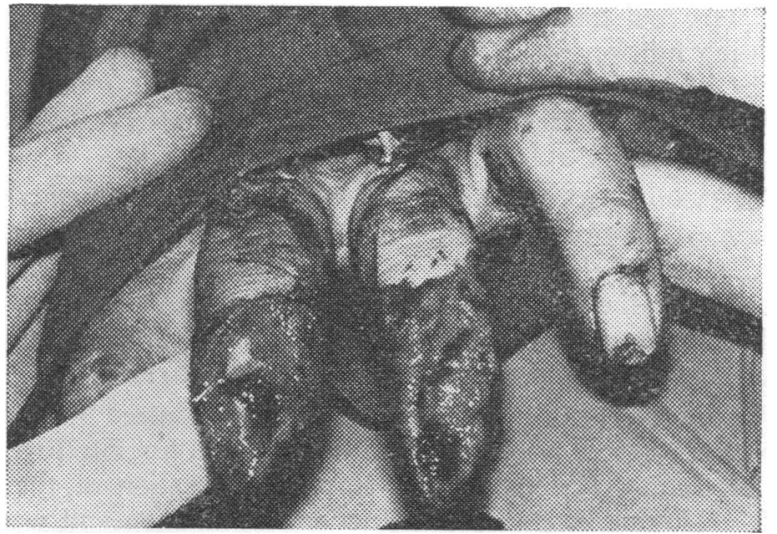

FIG. 2.-Case 21. Auger injury to left middle and ring fingers.

Four further injuries to the fingers and one to the toes (two resulting in partial amputations) were also seen as the result of insufficient care in the use of grain augers. In three cases the guard was not in place, and in a fourth the patient unwisely put his fingers through the guard to pull out a twig. This accident illustrates the inadequacy of some guards even when being used correctly.

Case 58.-Possibly the most serious accident in this group was experienced by a 47-year-old woman who worked on a turkey farm. While operating a tendon-pulling machine-a device which amputates the feet and avulses the long tendons of the legs of turkeysher right hand became caught in the machine, resulting in the avulsion of the index finger and second metacarpal, partial avulsion of the thumb, and extensive damage to the middle finger (Fig. 3). A grossly comminuted fracture of the first metacarpal was associated with avulsion of the thenar and interosseus muscles arising from that bone. Several other tendons, nerves, and muscles were injured in the metacarpal region. On the day of admission an extensive operation was performed to try to salvage as much of the hand as possible, and in particular the thumb. Thrombosis occurred, however, in the surviving vessels in the thumb, necessitating amputation of the thumb some three days later. Some eight and a half months after her accident she returned to work part-time. She was able to make a fairly good grip using her three remaining fingers. A thumb prosthesis was being considered when she was last seen.

Case 42.-The only serious injury inflicted by an animal was suffered by a 27 -year-old farm labourer who worked as a pigman. He was pored by a pig in the right thigh and leg, the wounds being heavily soiled. The thigh wound was 4 in. $(10 \mathrm{~cm}$.) long, but the underlying wound in the fascia lata and surrounding muscles reached 6 in. $(15 \mathrm{~cm}$.) in length. The 3-in. $(7 \cdot 5-\mathrm{cm}$.) lower leg wound was also laterally placed. So heavily soiled were the wounds that it

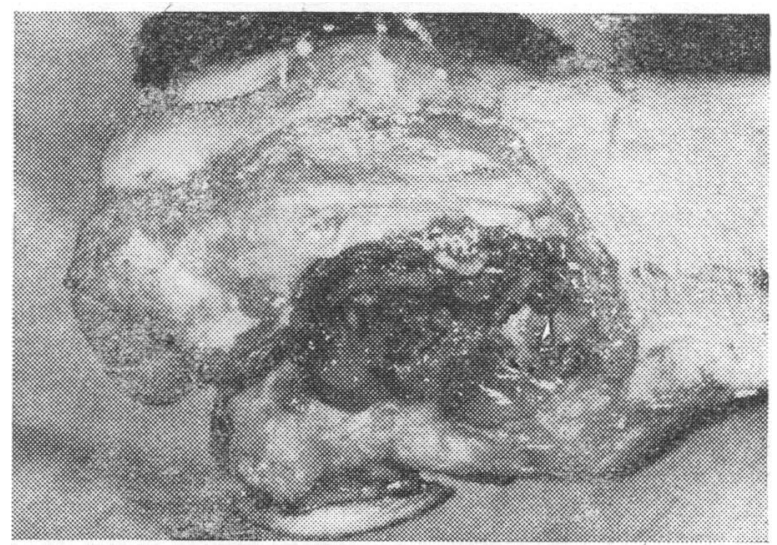

FIG. 3.-Case 58. Injury to right hand caused by turkey tendon-pulling machine.

was felt essential to administer antitetanus serum (A.T.S.) as well as beginning a course of adsorbed tetanus toxoid (A.T.T.). This was the only injury in the series in which A.T.S. was thought to be necessary. The wound became infected with Proteus and coliform organisms, necessitating extensive debridement and toilet on three occasions. When the wounds were finally clean and dry, split skin grafting to both sites was carried out and the patient was able to leave hospital some four weeks after his accident, though his leg was considerably wasted.

\section{Group 2. Crush Injuries and Direct Blows}

Thirty-five injuries were predominantly of this type. Ten resulted in fractures (three of which were compound). In 10 further cases of soft-tissue damage alone, lacerations were also present. Skin grafts were necessary in three of these cases. As might be expected with crush injuries, the distal parts of the limbs were affected in a high proportion of cases, the hand or fingers being involved in 21 patients and the feet in a further six. Fractures of the small bones of the hands and feet were sustained by six patients, including one partial amputation of an index finger ; dislocation of joints occurred in one patient.

The causes of these injuries were manifold, but trailer towbars and the tailboards of lorries were involved in seven instances. Other injuries were sustained when adjusting the hydraulics of tractors (two), from direct blows by animalshorses (one), cows (two) - and by the time-honoured method of hitting one's fingers with a hammer (two). Hands were also crushed in beet harvesters (one), corn elevators (one), and in a door which was unexpectedly shut by a bullock.

Of the remaining eight accidents, three were by far the most serious of this group.

Case 37.-An 8-year-old boy fell off a trailer and became trapped between a wheel and the side of the vehicle. He was dragged around two or three times before the vehicle stopped. He sustained considerable crush injuries to the chest, though, in fact, only one rib and clavicle were fractured. He had been rendered unconscious for a few minutes at the time of injury and was in a very drowsy state when first seen. He presented with the typical appearance of traumatic asphyxia, and showed some respiratory obstruction, particularly in expiration. He slowly recovered his normal mental state, the abnormal physical signs regressed, and he was allowed home some 11 days after admission.

Case 43.-A 20-year-old male farm worker sustained severe crush fractures of the skull when the tractor he was driving overturned. He was said to have been travelling at 8 m.p.h. (13 km.p.h.) when the tractor swerved on to a $1-\mathrm{ft}$. (30-cm.) high grass verge and overturned, possibly as the result of a sudden overcorrection on the part of the driver. He was unconscious when first seen and remained so until his death five days later. He had minor tire marks over the upper trunk and arms, and a compound 
fracture of the skull. He was bleeding from the nose and mouth and had gross periorbital and retrobulbar haematomata, which were under great tension from retrobulbar haemorrhage. Radiography revealed skull fractures of the right petrous bone and of the left frontal region, suggesting an anteroposterior crushing injury. Immediate craniotomy was performed, and after great difficulty the considerable arterial haemorrhage from the region of the base of the skull was successfully controlled. Artificial ventilation was essential throughout the postoperative period and hypertensive agents became increasingly necessary. The patient's condition slowly deteriorated until death occurred five days after the accident. Necropsy showed extensive fractures of the base of the skull involving all three cranial fossae.

Case 54.-In this accident, affecting a 15-year-old schoolboy, the tailboard of a trailer loaded with fertilizer fell heavily on to his left thigh. Though the blow was not sufficient to cause any bony injury, he suffered extensive skin loss and gross contusion of the soft tissues of the anterior aspect of the thigh. This was a major injury with considerable damage to muscular tissue, and necessitated admission for eight days and operation under general anaesthesia. Exploration, debridement, and toilet of the wound were followed by the application of a split skin graft to a large area. A second small graft was required some six weeks later. After almost five months of physiotherapy and observation he was discharged with full movements of the limb.

The final five accidents in this group involved kicks from a horse (one) causing a fractured rib, and from a bullock (one) causing bruising of the chest wall ; a falling tree trunk caused soft-tissue damage to the right leg of a tree-feller; a conveyer belt forcibly flexed a poultry worker's trapped left hand, fracturing his distal radius and ulna ; an aluminium spray boom, which fell $6 \mathrm{ft}$. $(1.8 \mathrm{~m}$.) on to a tractor driver, caused scalp lacerations.

\section{Group 3. Injuries from Falling from a Height}

Twenty-two injuries resulted from falls from a height, nearly all from vehicles, ladders, trees, buildings, and haystacks. Also included in this group are two schoolchildren who fell from horses, and one farm worker who became dizzy while lifting a heavy sack and fell, sustaining a minor head injury. Two further patients sustained fractured skulls as a result of falls, but each made a straightforward recovery (Cases 57 and 132). The driver of a beet plough was thrown clear when the plough hit a rock and overturned. He escaped with a bruised chest.

Case 35.-A 63-year-old farmer fell from a corn drill with a $1-\mathrm{cwt}$. (51-kg.) bag of fertilizer on his right shoulder. He did not attend for treatment for two weeks, at which time a partial tear of the right supraspinatus tendon with muscle-tearing was diagnosed. Recovery was still incomplete some nine months later.

Other falls resulted in fractures of the ribs, pubic ramus, femur, and tibia and fibula. A right Colles fracture, with derangement of the inferior radio-ulnar joint, was still requiring physiotherapy one year later, and will almost certainly result in some permanent disability. Several minor injuries were also treated. Eight of the 22 patients in this group sustained fractures as a result of their falls.

\section{Group 4. Ligamentous Sprains}

Fourteen patients suffered injuries from falling awkwardly while walking or from landing awkwardly while jumping down from a vehicle. The unevenness of the ground was in many cases a major contributory factor. The ankles and feet were concerned in 12 such cases, sprains of the lateral ligaments of the ankle being by far the most common injury (11 cases). Two such injuries were caused when patients were pushed over by horses. All those seen subsequently in the Accident Service made uneventful recoveries over a period of two to four weeks. The twelfth patient sustained an injury which was predominantly a tear of the anterior capsule of the ankle joint. Back sprains occurred in two patients.

\section{Group 5. Eye Injuries}

Of 12 patients in this group 11 complained of foreign bodies entering the eye. The foreign bodies consisted of such diverse objects as barley dust (two), pieces of metal (five)including two obtained while sharpening implements on grindstones-and chicken battery dust and grit (two). One such foreign body penetrated the cornea and entered the anterior chamber. The patient had been chopping sugar beet at the time of injury. The left cornea contained $\frac{1}{8}-\mathrm{in}$. (3-mm.) laceration. He was admitted and underwent magnetic removal of the foreign body and was an inpatient for four days. When last seen a small corneal scar remained. All other eye lesions healed uneventfully. The twelfth patient scratched his left cornea on a metal protrusion on a combine-harvester. This abrasion also healed uneventfully.

Although corneal foreign bodies are commonly seen in any accident service, it seems likely that the nature of a farmer's work would make him more liable to this particular injury than many other sections of the community.

\section{Group 6. Other Injuries}

Six patients do not fit satisfactorily into any of the above groups.

An unusual injury occurred to a 46-year-old farmer (Case 32). His coat caught in the power take-off of a tractor engine, throwing him on to his back. Fortunately the engine stalled, but he had already sustained a partial tear of the rotator cuff tendons of the left shoulder joint. Full recovery took nine months to obtain.

The second patient sustained a sprain of the first metacarpophalangeal joint of the left hand when it was forcibly extended. Another patient fell heavily on to both knees, resulting in synovitis of the left knee. A fourth patient fell awkwardly while carrying a $90-\mathrm{lb}$. (41-kg.) sack on his right shoulder and suffered capsular and muscular damage to that region.

The most serious injury in this group occurred to a man who jumped from a lorry, landed heavily, and forcibly inverted his left foot. He sustained a fracture-dislocation of the left ankle. He underwent open reduction and fixation and was an inpatient for five days.

The final unfortunate patient, a 24-year-old farm worker, gave a most exciting history of his stout efforts to recapture a bullock which had escaped from a field. He chased the animal for 5 miles $(8 \mathrm{~km}$.) before catching it, and by this time registered his first complaint-namely, exhaustion. He grasped the bullock by the horns, but in his scuffles with it it gave him a sharp kick in the abdomen, which was his second complaint. Gamely hanging on, he and his adversary proceeded to overturn a nearby beehive, which led to his third complaint of multiple bee stings. This was too much even for him, and he let go of the bullock, and in his efforts to escape from the bees fell several feet over a dike into a water-filled ditch, bruising himself en route (fourth complaint) and swallowing a considerable amount of rather stagnant water (fifth complaint). On finally arriving at the Accident Service a thorough examination showed no serious injuries. After some reassurance, a washand-brush-up, and a strong cup of tea he was able to return home in good spirits.

\section{Special Notes}

\section{Tetanus Prophylaxis}

It is the policy of the Accident Service at Addenbrooke's Hospital for all non-immune casualties-that is, all patients who have never received a course of tetanus toxoid during their lifetime-with minor, apparently uncontaminated, lacerations to be treated with a course of adsorbed tetanus toxoid $(0.5 \mathrm{ml}$. 
intramuscularly at their first attendance, followed by a second similar dose 6 to 12 weeks later and a third dose after a further 12 months). All non-immune casualties attending with deep or dirty lacerations, including burns, are given a similar course of A.T.T. plus a course of cloxacillin. In cases where the risk of tetanus infection is considered to be extremely high passive immunity is induced with A.T.S. together with active immunity by A.T.T. and a course of cloxacillin.

Of the 57 patients who attended with open wounds only five (about 9\%) were fully immunized against tetanus-that is, they had received a course or booster dose of A.T.T. within the previous five years. Twenty further patients $(35 \%)$ had at one time of their lives received a course of A.T.T., but had received no A.T.T. during the previous five years and so required a booster dose. A further 32 patients $(56 \%)$ had never been immunized against tetanus and therefore a full course of A.T.T. was begun. In one of these cases the risk of tetanus infection was considered to be particularly high (the patient having been gored by a pig and the wound being grossly contaminated) and A.T.S. was administered in addition to A.T.T. No cases of tetanus were seen as a result of farm accidents during the 12-month period.

As can be seen from the above figures, the state of immunity of these patients was extremely poor. In view of the fact that open wounds received in agricultural areas are particularly liable to tetanus infection, these figures are surprisingly low. It is surely necessary to publicize the dangers of tetanus infection more vigorously in rural areas, and encourage general practitioners and local hospitals to take every opportunity to immunize their patients so as to maintain the state of immunity of rural populations at the highest possible level.

\section{Wound Infections}

If wounds were thought to be contaminated and the risk of infection-tetanus or otherwise-to be high, a course of oral antibiotic would be prescribed prophylactically. In the present study this was carried out in 32 cases, including one patient in whom open reduction of a fracture-dislocation of the ankle was performed. Three of these cases subsequently developed very mild wound infections. The patient who had been severely gored by a pig developed more serious infection. This was successfully treated over a period of four weeks. Two further patients who presented at the Accident Service with wcunds already infected received courses of antibiotic.

Thus only 4 out of 55 patients $(7 \%)$ who attended with noninfected open wounds subsequently developed wound infections, and only one of these was troublesome. These figures suggest that even in wounds received in agricultural areas, where the risk of contamination and infection can be regarded as high, thorough toilet of the wound, rest of the injured part where necessary, and a prophylactic course of a suitable antibiotic (in nearly all cases penicillin) are successful in preventing subsequent wound infection.

\section{Discussion}

In 1967 the Ministry of Agriculture, Fisheries and Food reported 8,686 accidents and diseases in agriculture in England and Wales, of which $114(1.3 \%)$ were fatal. Table X shows

TABLE X.-Accidents and Diseases in Agriculture in England and Wales,

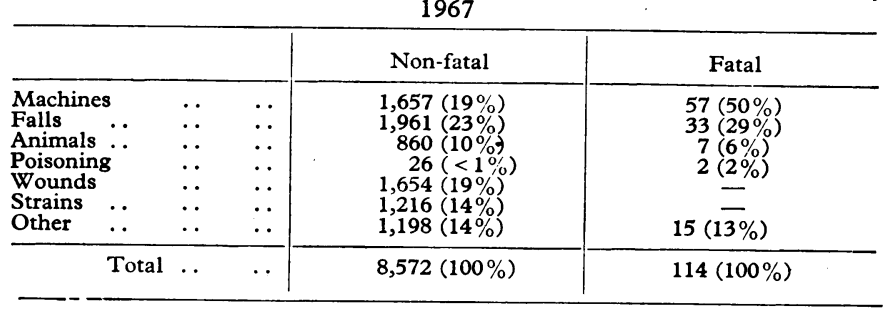

the major causes of these accidents. It should be noted that the figures for non-fatal accidents are incomplete. They show only those accidents reported by the Ministry of Social Security.

To my knowledge there is only one previous published study of agricultural accidents in the United Kingdom. In 1965 Rees reported a series of 14 tractor accidents seen over a period of four and a half years in mid-Wales and emphasized the dangers of these machines overturning.

\section{Machinery and Implements Involved in Accidents}

Farm machinery and implements were concerned in $66(50 \%)$ of the accidents studied in the present series (Table VIII). Table $\mathrm{X}$ shows that agricultural machinery was implicated in only $19 \%$ of non-fatal accidents and $50 \%$ of fatal accidents in England and Wales in 1967.

The considerable discrepancy between the Cambridge and national figures is due to a number of factors, notably incompleteness of the national figures, as already mentioned, and a different approach to categorizing the types and causes of injury. In the present series any accident involving a machine has been included in the total figure, whereas in the national figures falls from machines, for example, are listed as falls, and do not contribute to the total number of machinery accidents.

Almost every type of agricultural machine and tool is a potential source of injury to the farm worker. The tractor was involved in a larger number of accidents than any other single machine, and caused the only fatal injury in the present series. The trailer, however, was responsible for only two fewer injuries. The importance of the auger as a source of injury in what is predominantly a grain-orientated agricultural region is well illustrated by these figures.

\section{Tractor Accidents}

Tractor accidents account for about half of the fatal agricultural accidents in Ireland (O'Donnell, 1967), and for about $40 \%$ in England and Wales (Ministry of Agriculture, Fisheries and Food, 1967). The majority of these deaths are caused by overturning of the machine. Similar figures have been reported in the U.S.A. (Metropolitan Life Insurance Company, 1965). Falls from tractors also contributed appreciably to the mortality figures. One of the conclusions drawn from Rees's (1965) study of tractor accidents was that if a driver is injured when a tractor overturns the chances are more than one in four that he will be killed.

In the present series three vehicles overturned-two tractors and one beet plough. The driver of the beet plough was thrown clear and escaped with a bruised chest. The two tractor accidents illustrate admirably the safety value of a strong protective $\mathrm{cab}$ around the driver, for one tractor was fitted with such a $\mathrm{cab}$ and one was not. The protected driver received only a minor facial laceration and undisplaced fractures of the nasal bones (when the driver changed into top gear instead of reverse and plunged over the dike into a ditch), whereas the unprotected driver received multiple skull fractures and brain damage from which he subsequently died.

The dangers of the power take-off (a rapidly rotating shaft which enables the tractor engine to be used as a stationary source of power to run other agricultural machines) are well illustrated in the present series by the farmer whose coat caught in the power take-off, resulting in a partial tear of the rotator cuff tendons of his left shoulder (Case 32). This patient was fortunate, for I have seen one other patient who suffered a similar but very much more serious injury; as this occurred three years previously it is not included in this series. He was a middle-aged farmer whose coat caught in the power take-off of a tractor and was drawn into the engine, until his 
head and neck were pressing against the side of the tractor, the force fracturing his cervical vertebral column and resulting in a quadriplegia.

Accidents such as this should be extremely rare if all safety factors are attended to. Legislation requires the power take-off to be covered by a shield whenever the engine is in motion (Agriculture (Power Take-off) Regulations, 1957).

\section{Animals Involved in Accidents}

In the present series $13(10 \%)$ accidents involved farm animals (Table IX). The horse, bullock, and cow were most commonly involved, though the most serious injury was inflicted by a pig.

In 1967 animals accounted for 867 accidents (10\%) to farm workers in England and Wales (Table X). Of these, seven were fatal. Seventy-seven non-fatal and five fatal accidents resulted from attacks by bulls.

Wilson (1966) and Steele-Bodger (1969) have stressed the unpredictable nature of the bull, making it the commonest cause of injury to farm workers among farm animals. Wilson also drew attention to the serious nature of injuries caused by pigs, a fact well illustrated in the present series (Case 42).

\section{Accident Prevention}

Prevention is obviously the only real solution to accidents of any nature. In the United Kingdom regulations have been made under the Agriculture (Safety, Health and Welfare Provi- sions) Act, 1956, to reduce accidents to agricultural workers and children. Wilson $(1966,1969)$ has fully discussed such legislation in the United Kingdom.

Legislation alone, however, cannot prevent accidents, and the final responsibility lies with the farm worker to ensure that all safety precautions are followed; as shown by several of the accidents described in the present series, this is unfortunately not always the case.

I should like to thank Mr. A. G. Murley, Director of the Acciden: Service, Addenbrooke's Hospital, and Mr. D. Rosborough, senior orthopaedic surgical registrar, for considerable guidance and encouragement ; Mr. W. Lewin and Mr. J. Gleave, of the Department of Neurological Surgery, for permission to include patients under their care ; the receptionist, Miss D. Snell, sisters, and nursing staff of the Accident Service for their considerable clerical assistance ; and my fellow accident officers, whose co-operation greatly facilitated this study.

I am also grateful to Mr. G. S. Wilson, Chief Safety Inspector of the Ministry of Agriculture, Fisheries and Food, for his kind assistance in the preparation of this paper.

\section{REFERENCES}

Metropolitan Life Insurance Company (1965). Statistical Bulletin, 46, No. 8

Ministry of Agriculture, Fisheries, and Food (1967). Report of Safety, Health, Welfare, and Wages in Agriculture. London, H.M.S.O. O'Donnell, B. (1967). Fournal of the Irish Medical Association, 60, 47. Rees, W. D. (1965). British Medical fournal, 2, 63.

Steele-Bodger, A. (1969). Annals of Occupational Hygiene, 12, 79. Wilson, G. S. (1966). British Fournal of Industrial Medicine, 23, 1. Wilson, G. S. (1969). Annals of Occupational Hygiene, 12, 129.

\title{
Attenuation of Human Influenza A Viruses
}

\author{
A. S. BEARE,* M.B., M.C.PATH., D.T.M.\&H. ; M. L. BYNOE, $; \dagger$ M.B., D.T.M.\&H.
}

\begin{abstract}
Summary : The attenuation of two human influenza $A$ $S$ viruses has been carried out, using the selection of inhibitor-resistant strains and multiple passages at low temperatures. A virus related to A2/Tokyo/3/67 was obtained in an inhibitor-resistant form. When this was compared with the inhibitor-sensitive strain in a volunteer trial it was relatively non-pathogenic. The second virus, A2/Hongkong/1/68, was subjected to much longer treatment, but nevertheless remained slightly sensitive to serum inhibitor. When given to volunteers it was less pathogenic than before but attenuation was incomplete. A2/Hongkong/1/68 was also modified by passage at low temperatures. Many of these passages are apparently necessary for full attenuation.
\end{abstract}

All attenuated viruses were infective and antigenic.

\section{Introduction}

Live influenza vaccines are used in Russia for mass immunization, and, though protection rates have been variable, there are grounds for confidence in their immunological efficiency, provided that they are effectively administered and their virus

\footnotetext{
* Member, M.R.C. Scientific Staff, Common Cold Research Unit, Salisbury, Wiltshire.

t Dr. By'noe died on 5 June 1969.
}

components are antigenically suitable (McDonala et al., 1962 ; Slepushkin et al., 1967; Beare et al., 1968b, 1969). In the preparation of vaccines our own difficulties have centred on virus attenuation. Initially efforts were made to reduce pathogenicity by simple egg passage, since it had been suggested that the genetic instability of viruses was sufficient to permit this (Burnet and Bull, 1943), and indeed would make the preservation of human infectivity very difficult (Zhdanov, 1967). Experiments showed, however, that, while small changes appeared at first, these were final, and viruses remained substantially unchanged after many egg passages (Beare et al., 1968a).

Methods adopted by Russian workers have also included the testing in volunteers of viruses obtained from patients in the hope that some of them would prove non-pathogenic. These workers concluded from this that viruses resistant to serum inhibitors cause fewer reactions than those which are inhibitorsensitive (Soloviev et al., 1961, 1968 ; Smorodintsev et al., 1965). No publication has, however, appeared which proves that inhibitor resistance and lack of pathogenicity are regularly associated or that when inhibitor-resistant strains are derived from inhibitor-sensitive viruses they are more attenuated for man than their parents. Conventional attenuation methods have also been favoured by Smorodintsev et al. (1965), who have produced vaccines for children by passing viruses at $25^{\circ} \mathrm{C}$. This technique has now been adopted by Maassab $(1967,1969)$, 